\title{
Retraction Note: The hydrochemical framework of surface water basins in southern Ghana
}

\author{
Sandow Mark Yidana
}

Published online: 4 June 2013

(c) Springer-Verlag Berlin Heidelberg 2013

Retraction to: Environ Geol (2009) 57:789-796

DOI 10.1007/s00254-008-1357-2

The article is retracted at the author's request because it was previously published under the same title in Journal of Environmental Hydrology (Volume 16, paper 3, January 2008). The author submitted the article to Environmental Earth Sciences on an assumption that the editorial office of journal Journal of Environmental Hydrology had not proceeded to publish the paper.

The online version of the original article can be found under doi: $10.1007 / \mathrm{s} 00254-008-1357-2$.

S. M. Yidana $(\square)$

Department of Earth and Environmental Studies,

Montclair State University, 1 Normal Ave,

Montclair, NJ 07043, USA

e-mail: yidanas1@mail.montclair.edu 